\title{
Making Progress as Leaders among University Staff
}

\author{
Cheng Sim Quah",*, Sandra Phek Lin Sim² \\ ${ }^{1}$ Institute of Aminuddin Baki, Institut Aminuddin Baki Kampus Induk,Kementerian Pendidkan Malaysia Kompleks Pendidikan Nilai, \\ 71760 Bandar Enstek, Malaysia \\ ${ }^{2}$ Academy of Language Studies , University Teknologi MARA, Sarawak, Jalan Meranek, 94300 Kota Samarahan Campus, Malaysia \\ *Corresponding Author: csquah@iab.edu.my
}

Copyright (C) 2014 Horizon Research Publishing All rights reserved.

\begin{abstract}
This study examined the overview of how individuals in their respective teams operated and contributed to their organization. This study also identified the salient characteristics of how the respondents made progress as leaders in their respective faculties or departments towards identifying directions for innovative future practice through levels of professional training and length of service in an organization. The significant finding of this study is that it identified the salient criteria of progress making among the Malaysian university staff. Therefore, in general, this study could strengthen the role and responsibilities of Malaysian university staff as leaders. In particular, it will enhance the awareness among university staff pertinent to the leadership role towards their contribution to innovative initiatives. Moreover, the results of this study will be useful to examine the strengths and weaknesses of the university staff when contributing to innovative initiatives. This study employed the survey method purported to explore university staffs' views pertinent to the criteria of making progress as leaders. The instrument used for this study was adopted and adapted from the questionnaire of 'Are We Making Progress as Leaders?' by the Baldrige Criteria for Performance Excellence. Stratified-random sampling was employed to determine the samples representing the population of lecturers in the study, involving 123 lecturers in one of the local universities in Malaysia. The main method employed to analyze the data is descriptive and inferential statistics. This study found that the respondents have the propensity in emphasizing customer focus criteria, followed by leadership. Thus, this indicates that customer focus criteria and leadership are the two areas which were perceived by the respondents to be of the greatest importance in making progress as leaders. Conversely, operational force criteria have the lowest mean. The findings of the study proved that significant difference at the $p<.05$ level occurred for four criteria namely Strategic Planning, Customer Focus, Result and Innovative category in terms of length of service. Likewise, in terms of levels of professional training, there was also a significant difference at the $p<.05$ level for Leadership, Customer Focus, Work Focus and Operational Force Criteria. Relatively, the actual difference in mean scores for levels of professional training
\end{abstract}

was higher than mean scores for the length of service. In terms of relationship between the professional training level and the length of service among the university staff towards innovation, findings showed that there was only a significant relationship between the professional training level and the length of service of $4-6$ years among the university staff (Likelihood Ratio $=28.500, \mathrm{df}=12, \mathrm{p}<0.5$ ). The rest of the groups based on the length of service showed that there was no significant relationship with the professional training level towards innovation. Moreover, results of the study on directional measures depicted that the relationship for the length of service of 4-6 years with professional training level among the university staff is quite weak with eta $=0.07$. Leadership criteria were perceived as vital criteria in making progress as leaders. This stems from the fact that good organisation management lies on the shoulders of the key leaders who illuminate the path to be followed by the group members.

Keywords Leadership, Strategic Planning, Customer Focus, Innovation, Work Force, Operational Force

\section{Introduction}

Every organization has to be committed to the relentless pursuit of progress if it wants to stay vibrant and relevant (Davis, 2007, p. 34) [1]. In fact, institutions really need leaders who are passionate about helping staff to learn. Developing leaders with these qualities for every institution is vital where performance generally lags behind. Thus, improving organization leadership requires a system with a sharp focus on improving skills and abilities of the staff. There are many different ways that leadership happens. Sometimes a single individual plays a major role in making it happens. Sometimes, it simply emerges in the conversations and interactions among people working together. Sometimes, different people play different roles to bring it about. Both formal and informal processes can make it happen (McCauley, 2011) [2].

Importantly, every institution needs access to a ready 
supply of well-prepared leaders in taking steps to redesign university-based leadership preparation programs to emphasize who can lead improvement. Institution needs leaders who are prepared to plan and implement institution improvement strategies from their first day on the job (Southern Regional Education Board, 2007) [3]. The primary mission of leadership in any organization is to focus on capability of providing energy and managing resources necessary for the success of the organization. In fact, any organization could not operate efficiently and effectively without leaders and without teams. Particularly, leaders are essential if an organization is to meet its goals. One leader in isolation does not lead an organization to success. The senior management team working together is essential to navigate in these increasingly complex and challenging times and can positively affect the bottom line. This view is shared by Nonaka (1991) [4] who perceived middle management as the most important to help transmit information into useful knowledge by providing conceptual frameworks for its staff to be involved in innovative initiatives. Conversely, an ineffective team can impact morale, staff confidence, and consume precious organizational resources (Bonner, 2010, p.1) [5]. According to Nanus and Dobbs (1999) [6], leaders must initiate and champion the strategy process and insure that the resulting strategy is fully communicated to and endorsed by all key stakeholders. Leaders also must take all necessary steps in order to see that the strategy is fully implemented.

Leadership practice is what connects policy to performance in an organization. Importantly, organization's members should take every opportunity to reflect on their performance and identify the skills needed to develop and become more effective leaders. It is important to understand what this proposition means in order to grasp what effective practice looks like. Practice is not a personal attribute or characteristic of leaders; it is a collection of patterned actions, based on a body of knowledge, skill and habits of mind that can be objectively defined, taught and learned (Elmore, 2006) [7]

\section{Objectives of the Study}

This study surveyed 123 university staff who are leading or are part of their leadership team. It examined the overview of how individuals in their respective teams operated and contributed to their organization. Besides that, this study also identified the salient characteristics of how the respondents made progress as leaders in their respective faculties or departments towards identifying directions for innovative future practice through levels of professional training and length of service in an organization.

\section{Research Questions}

1) What are the salient criteria in making progress as leaders among the University Staff?
2) Is there any significant difference on the criteria of making progress in terms of the length of service in an organization?

3) Is there any significant difference on the criteria of making progress in terms of the levels of professional training in an organization?

4) Is there a relationship between the professional training level and the length of service among university staff towards innovation?

5) To what extent do the length of service and the level of professional training contributed towards innovative products among University Staff?

\section{Significance of the Study}

Countries or state should provide guidelines to assist universities in recruiting and preparing a high-quality pool of potential leaders to meet current and projected needs. A key element in this design is the "leadership succession plan" to identify promising staff and create early opportunities for them to develop leadership skills (Southern Regional Education Board, 2007) [3]. Thus, the significant finding of this study is that it identified the salient criteria of progress making among the Malaysian university staff. Therefore, in general, this study could strengthen the role and responsibilities of Malaysian university staff as leaders. In particular, it will enhance the awareness among university staff pertinent to the leadership role towards their contribution to innovative initiatives. Moreover, the results of this study will be useful to examine the strengths and weaknesses of the university staff when contributing to the innovative initiatives.

This study focuses on three vital variables, namely the length of service, level of professional training and innovative initiatives. With the rapidly changing society, the 21 st-century workforce is global, highly connected, technology-savvy and demanding. Not only has technology become a critical and pivotal part of human resources but the length of service and the level of professional training are vital factors to maintain organizational progress. In order to keep pace with the $21^{\text {st }}$-century workforce, organizations need ambitious, passionate and purposeful employees. Thus, millennials are the major force but so are older workers, who remain engaged and valuable contributors. Unfortunately, critical new skills are scarce and their uneven distribution around the world is forcing companies to develop innovative new ways to find people, develop capabilities and share expertise (Global Human Capital Trends 2014, p. 2) [8]. Thus, this study emphasized the length of service and the level of professional training towards innovative initiatives to fulfill the needs of the $21^{\text {st }}$-century workforce due to the fact that trained staff is better equipped to meet the divergent needs of an organization. Moreover, the relationships between these two factors are very important in examining the contribution to innovative initiatives. 


\section{Materials and Methods}

\section{Research Design}

This study employed the survey method purported to explore university staffs' views pertinent to the criteria of making progress as leaders. The instrument used for this study was adopted and adapted from the questionnaire of 'Are We Making Progress as Leaders?' by the Baldrige Criteria for Performance Excellence. There were a total of 40 questions in the areas of leadership, strategic planning, customer focus, measurement, work force, operational force and organization's results. This compatible tool is to examine the perceptions of the staff from an organization to agree with those of their workforce. Five additional items associated with innovative elements were created by the authors to incorporate with the other seven criteria. Respondents were asked to rate each of these different attributes on a scale of 1 to 5 (where 1 is 'strongly disagree' and 5 is 'strongly agree').

In terms of the psychometric of this Baldrige instrument, the system operations of the targeted university are composed via the six Baldrige Categories. Three important roles from the six Baldrige categories for this study are purported to strengthen university staff competitiveness; guide university planning and opportunities for learning and lastly improve university performance practices as well as overall organizational effectiveness. The survey invited respondents to assess the importance of certain key attributes or characteristics of responsible leadership. This tool will help the staff to focus on their improvement and identify the key attributes or characteristics of responsible leadership on areas needing the most attention and address issues critical to their respective organization's success. In terms of the psychometrics context of the instrument, prior to the actual survey, the questionnaire was pilot tested in another branch of the university in another state of Malaysia to check the reliability of the items (Cronbach, 1991) [9]. Results revealed that all the items in every section of the questionnaire were reliable as the Cronbach Alpha values ranged between 8.4 to 9.1 .

\section{Sample Survey}

This study was carried out in a university in the state of Sarawak in Malaysia. This university was established in 1973 and it offers programmes ranging from diploma, degree, masters to doctorate levels. In addition to teaching, every lecturer is required to participate in research and consultancy work, and to be involved in other scholarly activities such as participation in seminars and conferences, publication and writing. Moreover, as a growing university, it encourages its staff to be involved in invention and innovation events. The participation and achievement of lecturers from this university in invention and innovation events was very promising, winning several gold, silver and bronze medals at university, national and international levels between 2007 and 2013. The encouraging performance of this university has prompted the researchers to examine the overview of how individuals in their respective teams operated and contributed to this organization. This study also identified the salient characteristics of how the respondents made progress as leaders in their respective faculties or departments towards identifying directions for innovative future practice through levels of professional training and length of service in an organization.

Stratified-random sampling was employed to determine the samples representing the population of lecturers in the study, involving 123 lecturers in one of the local universities in Malaysia. There were thirteen faculties involved in this study. At the University level, stratified sampling was employed to select the possibility of lecturers from each faculty. Simple random sampling was conducted at the faculty level to select 12 lecturers for all the 13 faculties. The respondents in the study consisted of Heads of Department $(1.6 \%)$, Heads of Unit $(2.4 \%)$, Heads of Studies $(2.4 \%)$, Course Coordinators (4.1\%), Permanent Lecturers $(80.5 \%)$ and Full Time-Part Time Lecturers (8.9\%).

\section{Data analysis methods}

The main method employed to analyze the data is descriptive and inferential statistics. Due to the fact that the questionnaire items are in nominal and ordinal data, the authors used the distribution of frequencies, percentages, means, ANOVA and Crosstab to analyze and describe the results of the research findings.

\section{Findings}

\section{RQ1: What are the salient criteria of making progress among the University Staff?}

Table 1 and Figure 1 depict the mean scores of the seven criteria of making progress as leaders. The result indicated that most of the participants agreed with all the items of the criteria of 'making progress as leaders'. There were seven out of forty items that have a higher mean score from the range of 4.00 to 4.41 . The awareness of who is the most important customer in their faculty/department has the highest mean score (4.41), followed by the awareness of organization's mission (4.15). A total of 54.5 percent as well as 43.9 percent of participants knew who their most important customer is in their respective faculty/department. Likewise, a total of 69.9 percent of the participants agreed and 23.6 percent strongly agreed that their Faculty/Department/Centre knew their organization's mission in terms of what they are trying to accomplish. Conversely, the operational force criteria (participants can get everything that they need to do their jobs) has the lowest mean score of 3.07 . 
Table 1. Criteria of Making Progress as Leaders

\begin{tabular}{|c|c|c|}
\hline Criteria of Making Progress as Leaders & Mean & SD \\
\hline \multicolumn{3}{|l|}{ Leadership Criteria } \\
\hline L1 knows my organization's mission (what we are trying to accomplish). & 4.15 & 0.587 \\
\hline L2 knows my organization's vision (where it is trying to go in the future). & 4.0 & 0.653 \\
\hline L3 uses my organization's values to guide me and my organization. & 3.8 & 0.732 \\
\hline L4 creates a work environment that helps me to do my jobs & 3.76 & 0.811 \\
\hline L5 The leadership team shares information about the organization & 3.79 & 0.842 \\
\hline L6 The leadership team asks me what I think (my opinion/ideas). & 3.45 & 0.898 \\
\hline \multicolumn{3}{|l|}{ Strategic Planning Criteria } \\
\hline SP8 My organization encourages totally new ideas (innovation). & 3.78 & 0.815 \\
\hline SP9 I know the parts of my organization's plans that will affect me and my work. & 3.97 & 0.712 \\
\hline SP10 I know how to tell if I am making progress in my work which is part of the organization's plan & 3.67 & 0.754 \\
\hline SP11 My organization is flexible and can make changes quickly when needed. & 3.51 & 0.953 \\
\hline \multicolumn{3}{|l|}{ Customer Focus Criteria } \\
\hline CF13 I regularly ask my customers what they need and want. & 3.93 & 0.755 \\
\hline CF14 I ask if my customers are satisfied or dissatisfied with my work. & 3.92 & 0.855 \\
\hline CF15 I am allowed to make decisions to solve problems for my customers. & 3.85 & 0.713 \\
\hline CF16 I also know who my organization's most important customers are. & 4.14 & 0.618 \\
\hline \multicolumn{3}{|l|}{ Measurement Criteria } \\
\hline M17 I know how to measure the quality of my work. & 3.97 & 0.639 \\
\hline M18 I use this quality measurement information to make changes that will improve my work. & 3.77 & 0.818 \\
\hline M19 I know how the measures that I use in my work fit into my organization's overall measures of & 3.48 & 0.772 \\
\hline M20 I get all the quality measurement information that I need to assist me in my work. & 3.39 & 0.929 \\
\hline M21 I know how my organization as a whole is doing. & 3.71 & 0.866 \\
\hline \multicolumn{3}{|l|}{ Workforce Criteria } \\
\hline WF23 The leadership team encourages and enables me to develop my job skills so I can advance & 3.81 & 0.833 \\
\hline WF24 I am recognised for my work. & 3.63 & 1.011 \\
\hline WF25 My organization has a safe workplace. & 3.98 & 0.945 \\
\hline WF26 My leaders and my organization care about my Faculty/Department/Centre's workforce. & 3.41 & 1.032 \\
\hline WF27 The workforce in my Faculty/Department/Centre is committed to my organization's success. & 3.9 & 0.694 \\
\hline \multicolumn{3}{|l|}{ Operational Force Criteria } \\
\hline OF29 My organization has good processes for doing its work. & 3.5 & 0.762 \\
\hline OF30 I have control over my personal work processes. & 4.02 & 0.593 \\
\hline OF31 My organization is prepared to handle an emergency. & 3.41 & 0.723 \\
\hline \multicolumn{3}{|l|}{ Result Criteria } \\
\hline R33 My customers are satisfied with my work. & 4.07 & 0.539 \\
\hline R34 The workforce in my Faculty/Department/Centre knows how well my organization is doing & 3.24 & 0.97 \\
\hline R35 My organization has the right people and skills to do its work. & 3.59 & 0.838 \\
\hline R36 My organization removes things that get in the way of progress. & 3.37 & 0.863 \\
\hline R37 My organization obeys laws and regulations. & 3.98 & 0.9 \\
\hline R38 My organization practices high standards and ethics. & 3.44 & 0.985 \\
\hline R39 My organization helps me to contribute to the community. & 3.79 & 0.792 \\
\hline R40 I believe my organization is a good place to work. & 3.91 & 0.71 \\
\hline \multicolumn{3}{|l|}{ Innovative Criteria } \\
\hline Inno41 The leaders of this organisation stress on the importance of innovation. & 4.01 & 0.773 \\
\hline Inno42 The leaders of this organisation inspire me to experiment on innovative ideas. & 3.50 & 0.978 \\
\hline Inno43 I try my best to achieve a particular outcome when I am assigned a task. & 4.33 & 0.568 \\
\hline Inno44 I try to reduce unexpected outcome in my work as much as possible. & 4.01 & 0.763 \\
\hline Inno45 I always like challenges in my work. & 4.07 & 0.827 \\
\hline
\end{tabular}




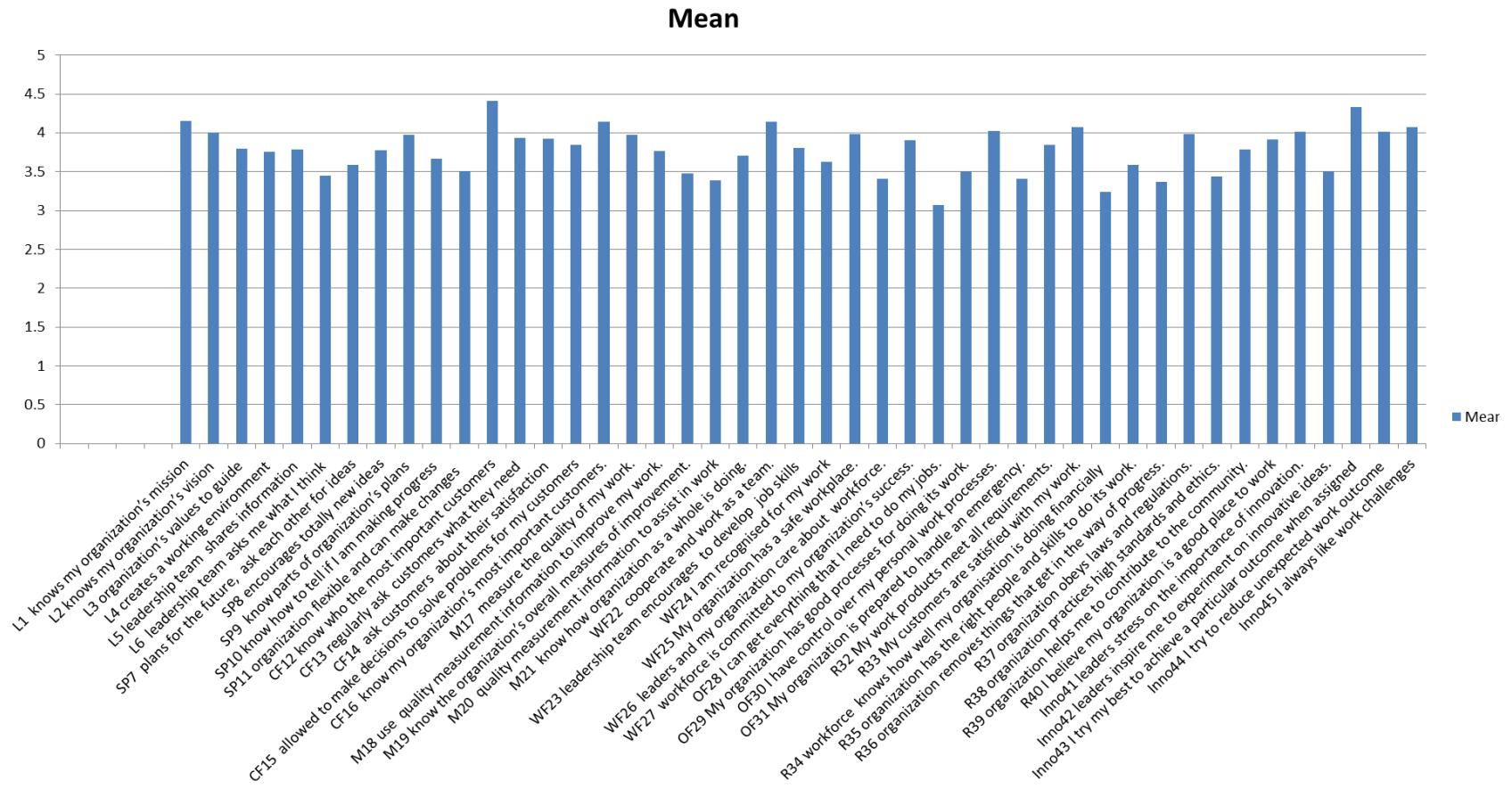

Figure 1. Criteria of Making Progress as Leaders

In terms of leadership criterion, more than eighty percent of the respondents agreed or strongly agreed on the statement related to organization's mission and vision. These two items have the highest mean compared with other leadership criterion. The highest mean indicates that the respondents' faculty knew their organization's mission with the mean of 4.15 , followed by organization's vision with the mean of 4.00 . This finding implies that their faculty knew what they are trying to accomplish and where they are heading for in their future. In fact, mission and vision statements are indispensable communication tools. Referring to the strategic planning criteria, the respondents knew the parts of their organization's plans with the highest mean of 3.97. In contrast, only 48 percent of respondents declared that their organization is flexible and can make changes quickly when needed.

In terms of customer focus criteria, this criteria has the highest mean score of all the criteria with the mean value of 4.41. More than ninety percent of the respondents agreed and strongly agreed with the item that they knew who their most important customers are. Where as, for the measurement criteria, the finding in this study showed that the respondents knew how to measure the quality of their work. This item has the highest mean score of 3.97 in the measurement criteria. Relatively, work focus criteria has the third highest mean score of all the criteria with the mean value of 4.14. More than ninety percent of the respondents agreed and strongly agreed upon the item that they cooperate and work as a team. Pertaining to the operational force criteria, respondents of the study admitted that they have control over their personal work processes with the mean value of 4.02. In terms of result criteria, the findings in Table 1 and Figure 1 indicated that the respondents felt that their customers are satisfied with their work with the highest mean of 4.07 , followed by the item about their organization obeys laws and regulations. In terms of innovative criteria, findings showed that the respondents were trying their best to achieve a particular outcome when they are assigned a task. But unfortunately, findings also indicated that their organisation leaders inspired them less to experiment on innovative ideas with the lowest mean of 3.50 .

The findings, in general, imply that customer focus and leadership criteria were the most preferred categories in 'making progress as leaders' among participants as academicians. However, finding in this study indicated that operational force criteria was the least preferred criteria. Hence, it shows that two salient criteria in making progress as leaders are the acknowledgement of important customers in their respective faculty or department (customer focus criteria) and the awareness of organization's mission (leadership criteria). The findings showed that respondents of the study preferred a few salient criteria in making progress as leaders such as below:

1. I know who my faculty/department most important customers are (mean=4.41).

2. My faculty/ department know my organization's mission. (mean=4.15)

3. I also know who my organization's most important customers are. (mean=4.14)

4. I cooperate and work as a team. $($ mean $=4.14)$

5. My customers are satisfied with my work. (mean=4.14)

6. I have control over my personal work processes. (mean=4.14)

7. My faculty/ department know my organization's vision. $($ mean $=4.14)$ 


\section{Eight Categories of Criteria}

This study has used eight indicators to track the progress of creating a leadership system that produces cutting-edge of making progress as leaders. Among the eight criteria, Figure 2 depicts that respondents of the study have the propensity in emphasizing custormer focus criteria, followed by leadership. Thus, this indicates that custormer focus criteria and leadership are the two areas which were perceived by the respondents to be of the greatest importance in making progress as leaders. Conversely, operational force criteria has the lowest mean. In fact, the authors believe that operational force is also a vital element towards an organization's success. By holding people accountable, insisting that they deal with tough issues and helping them manage dissent, leaders can help make leadership happens. Organizations and teams that learn to harness conflict and use it constructively come up with more creative ideas and innovative solutions. Healthy conflict and debate are essential precursors for organizational learning and growth. Sadly, in most organizations, this adaptive work is usually avoided, more dirt is swept under the carpet, and the organization suffers (Souba, 2007, p. 4) [10].

\section{RQ2: Is there any significant difference on the criteria of making progress in terms of the length of service}

A one-way between groups analysis of variance was conducted to explore the length of service on criteria of making progress as leaders. Respondents were divided into 6 groups (Group 1: 1- 3 years; Group 2: 4 - 6 years; Group 3: 7 - 9 years; Group 4: 10 - 12 years; Group 5: 13 - 15 years and Group 6: More than 15 years). Levene's test for homogeneity of variances was employed to test whether the variance in scores is the same for each of the 6 groups in terms of length of service. A few of the criteria needed to consult the table in the output headed Robust test of Equality of Means because it has been found that the analysis has violated the assumption of homogeneity of variance as the Sig. Value is greater than .05. Welsh and Brown-Foythe test in Robust are used when the assumption of the homogeneity of variance is violated.

The findings of the study proved that significant difference at the $\mathrm{p}<.05$ level occurred for four criteria of making progress categories namely Strategic Planning, Customer Focus, as well as Result and Innovative category in terms of length of service. For the strategic planing criteria, there was a significant difference in the length of service, $\mathrm{F}(5$, $52.505)=2.622, \mathrm{p}<.05$ for item SP10 (I know how to tell if I am making progress in my work which is part of the organization's plan) with the Sig. Value $=.034$. Likewise, for the customer focus criteria, there was a significant difference in the length of service, $\mathrm{F}(5,117)=2.483, \mathrm{p}<.05$ for item CF16 (I also know who my organization's most important customers are) with the Sig. Value $=.035$. Moreover, post-hoc comparisons using the Tukey HSD test as illustrated in Table 2 indicated that the mean score for Group 7 - 9 years was significantly different from Group 1 - 3 years. Despite reaching statistical difference, the actual difference in mean scores between the groups was quite small (Mean Difference $=.724 *$ ).

Table 2. Post-Hoc Comparison for Length of Service on Customer Focus Criteria

\begin{tabular}{ccccc}
\hline $\begin{array}{c}\text { Dependent } \\
\text { Variable }\end{array}$ & $\begin{array}{c}\text { (I) Length } \\
\text { of Service }\end{array}$ & $\begin{array}{c}\text { (J) Length of } \\
\text { Service }\end{array}$ & $\begin{array}{c}\text { Mean } \\
\text { Difference } \\
\text { (I-J) }\end{array}$ & $\begin{array}{c}\text { Sig } \\
\cdot\end{array}$ \\
\hline $\begin{array}{c}\text { Customer } \\
\text { Focus_CF16 }\end{array}$ & $7-9$ years & $1-3$ years & $724^{*}$ & $\begin{array}{c}.00 \\
2\end{array}$
\end{tabular}

*. The mean difference is significant at the 0.05 level.

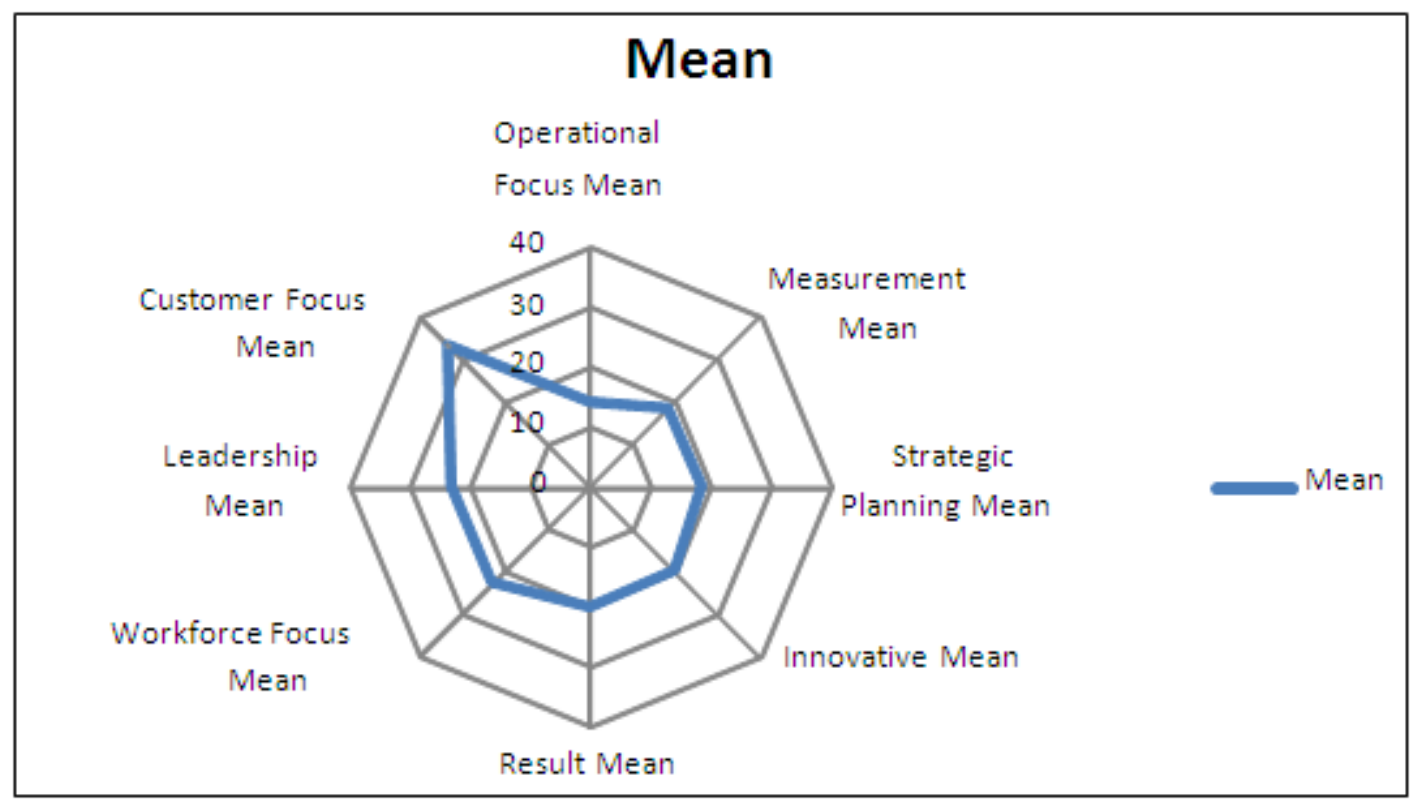

Figure 2. Eight Categories of Criteria 
Pertaining to the result criteria, there are two items; R32 (My work products meet all requirements) and R37 (My organization obeys laws and regulations) which showed that there was also a significant difference in result criteria on length of service. For item R32 that is related to result criteria, there was also a significant difference in result criteria on length of service with $F(5,53.984)=2.979, p<.05$. Based on the post-hoc comparisons using the Tukey HSD test, the results indicated that the mean score for group $4-6$ years and group $1-3$ years, $4-6$ years and group $10-12$ years and 4 6 years and group of more than 15 years are significantly different from one another regarding participants' work products meet all requirements in terms of length of service scores. Nevertheless, the actual difference in mean scores between the groups was quite small.

For item R37, there was also a significant difference in the length of service, $F(5,53.434)=2.992, \mathrm{p}<.05)$ with the Sig. value $=.019$. Based on the post-hoc comparisons using the Tukey HSD test, results in Table 3 indicated that the mean score for group 4 - 6 years and group $1-3$ years, 4 - 6 years and group $10-12$ years and $4-6$ years and group more than 15 years are significantly different from one another regarding 'My organization obeying laws and regulations' in terms of length of service scores. However, the actual difference in mean scores between the groups was quite small.

Table 3. Post-Hoc Comparison for Length of Service on Result Criteria

\begin{tabular}{ccccc}
\hline $\begin{array}{c}\text { Dependent } \\
\text { Variable }\end{array}$ & $\begin{array}{c}\text { (I) Length } \\
\text { of Service }\end{array}$ & $\begin{array}{c}\text { (J) Length } \\
\text { of Service }\end{array}$ & $\begin{array}{c}\text { Mean } \\
\text { Difference } \\
\text { (I-J) }\end{array}$ & Sig. \\
\hline Result_R37 & 7 -9 years & $\begin{array}{c}\text { More than } \\
15 \text { years }\end{array}$ & $1.016^{*}$ & .031 \\
\hline
\end{tabular}

*. The mean difference is significant at the 0.05 level.
Likewise, the innovative criteria also showed significant difference that occurred for two items: R42 and R44 on length of service. It was found that item R42 (The leaders of this organization inspire me to experiment on innovative ideas) is significantly different on the length of service, $F(5$, $54.181)=3.884, \mathrm{p}<.05($ Sig. Value $=.004)$. Item R44 (I try to reduce unexpected outcome in my work as much as possible) is also significantly different on the length of service, $F(5,117)=2.943, p<.05$. Based on the post-hoc comparisons using the Tukey HSD test, results in Table 4 indicated that the mean score for group 7 - 9 years was significantly different from group $1-3$ years. Despite reaching statistical difference, the actual difference in mean scores between the groups was quite small (Mean Difference $=2.57895^{*}$ and $2.22760^{*}$ ).

Table 4. Post-Hoc Comparison for Length of Service on Innovative Criteria

\begin{tabular}{ccccc}
\hline $\begin{array}{c}\text { Dependent } \\
\text { Variable }\end{array}$ & $\begin{array}{c}\text { (I) Length } \\
\text { of Service }\end{array}$ & $\begin{array}{c}\text { (J) Length } \\
\text { of Service }\end{array}$ & $\begin{array}{c}\text { Mean } \\
\text { Difference } \\
\text { (I-J) }\end{array}$ & Sig. \\
\hline $\begin{array}{c}\text { Innovative } \\
\text { Mean }\end{array}$ & $7-9$ years & $1-3$ years & $2.57895^{*}$ & .022 \\
& 7 - 9 years & $4-6$ years & $2.22760^{*}$ & .026 \\
\hline
\end{tabular}

* The mean difference is significant at the 0.05 level.

RQ3: Is there any significant difference on the criteria of making progress in terms of the levels of professional training in the organization?

There was a significant difference at the $p<.05$ level for items in criteria of making progress scores for four categories in terms of levels of professional training in the organization namely Leadership, Customer Focus, Work Focus and Operational Force Criteria.

Table 5. Post-Hoc Comparison for Levels of Professional Training on Leadership Criteria

\begin{tabular}{|c|c|c|c|c|}
\hline Dependent Variable & $\begin{array}{l}\text { (I) Level of } \\
\text { Professional } \\
\text { Training }\end{array}$ & $\begin{array}{l}\text { (J) Level of } \\
\text { Professional } \\
\text { Training }\end{array}$ & $\begin{array}{c}\text { Mean } \\
\text { Difference } \\
(\mathrm{I}-\mathrm{J})\end{array}$ & Sig. \\
\hline Leadership_L4 & International & $\begin{array}{l}\text { Local and } \\
\text { International }\end{array}$ & $.581^{*}$ & .012 \\
\hline Leadership_L6 & International & Local & $.544^{*}$ & .01 \\
\hline
\end{tabular}

*. The mean difference is significant at the 0.05 level.

Table 6. Post-Hoc Comparison for Levels of Professional Training on Customer Focus Criteria

\begin{tabular}{ccccc}
\hline Dependent Variable & $\begin{array}{c}\text { (I) Level of } \\
\text { Professional } \\
\text { Training }\end{array}$ & $\begin{array}{c}\text { (J) Level of } \\
\text { Professional } \\
\text { Training }\end{array}$ & $\begin{array}{c}\text { Mean } \\
\text { Difference } \\
\text { (I-J) }\end{array}$ & Sig. \\
\hline Customer Focus_CF15 & International & Local & $.424^{*}$ & .018 \\
\hline
\end{tabular}


Based on the Leadership criteria, three items showed significant difference in the level of professional training in the organization, namely; L4 (My faculty/ department creates a work environment that helps me to do my jobs) with $\mathrm{F}(2,120)=4.376, \mathrm{p}<.05, \mathrm{~L} 5$ (The leadership team shares information about the organization) with $\mathrm{F}(2,73.803)$ $=2.870, \mathrm{p}<.05$ and L6 (The leadership team asks me what I think (my opinion/ideas) with $\mathrm{F}(2,69.756)=6.428, \mathrm{p}<.05$. As displayed in Table 5 of the post-hoc comparisons using the Tukey HSD test, results indicated that for item L4, there was a significant difference between the group with international level of professional training and the group with both local and international level of professional training. These findings indicate that there was a significant difference for the respondents who went through international level of training and also those who went through both levels of training as they felt that their faculty or department creates a work environment that helps them to do their jobs. The actual difference in mean scores between the groups was quite moderate with the mean difference of $0.581^{*}$. Conversely, for item L6, the results of post-hoc comparisons test as observed in Table 5 indicated that only the group with international level of professional training and the group with local level of professional training exhibited significant difference from one another in terms of asking the respondents for their opinion or ideas by their leadership team.

For Customer Focus criteria, findings revealed that there were significant difference in the levels of professional training in the organization for item CF15 (I am allowed to make decisions to solve problems for my customers) with $\mathrm{F}(2,120)=3.803, \mathrm{p}<.05$ for item CF 15 . The results of the post-hoc comparisons using the Tukey HSD test in Table 6 indicated that there was a significant difference between the group with international level of training and the group with local level of training. These findings indicate that there was a significant difference for the respondents who went through international level of training and also those who went through local training as they felt that they were allowed to make decisions to solve problems for their customers. The actual difference in mean scores between the groups was quite moderate with the mean difference of 0.424*.

In relation to the work force criteria, there are two items; WF24 (I am recognised for my work) and WF25 (My organization has a safe workplace) which showed that there was also a significant difference on levels of professional training in the organization. For item WF24, a significant difference with $\mathrm{F}(2,70.912)=2.979, \mathrm{p}<.05$ and for the item WF25 a significant different with $\mathrm{F}(2,120)=4.028, \mathrm{p}<.05$ existed. Based on Table 7, results of the post-hoc comparisons using the Tukey HSD test indicated that only the group with international level of training and the group with local level of training manifested significant difference from one another. These findings indicate that there was a significant difference for the respondents who went through international level of training and also those who went through local training as they felt that they were recognised for their work. The actual difference in mean scores between the groups was quite moderate with the mean difference of $0.525^{*}$. In contrast, for item WF25, results of the post-hoc comparisons test indicated that only the group with international level of professional training and the group with both local and international level of professional training demonstrated significant difference from one another in terms of a safety workplace in their organization. The actual difference in mean scores between the groups was quite moderately high with the mean difference of $0.645^{*}$

Table 7. Post-Hoc Comparison for Levels of Professional Training on Workforce Focus Criteria

\begin{tabular}{ccccc}
\hline Dependent Variable & $\begin{array}{c}\text { (I) Level of } \\
\text { Professional } \\
\text { Training }\end{array}$ & $\begin{array}{c}\text { (J) Level of } \\
\text { Professional } \\
\text { Training }\end{array}$ & $\begin{array}{c}\text { Mean } \\
\text { Difference } \\
\text { (I-J) }\end{array}$ & Sig. \\
Workforce Focus_WF24 & International & Local & $.525^{*}$ & .048 \\
Workforce Focus_WF25 & International & $\begin{array}{c}\text { Local and } \\
\text { International }\end{array}$ & $.645^{*}$ & .019 \\
\hline
\end{tabular}

* The mean difference is significant at the 0.05 level.

Table 8. Post-Hoc Comparison for Levels of Professional Training on Operational Focus Criteria

\begin{tabular}{ccccc}
\hline Dependent Variable & $\begin{array}{c}\text { (I) Level of } \\
\text { Professional } \\
\text { Training }\end{array}$ & $\begin{array}{c}\text { (J) Level of } \\
\text { Professional } \\
\text { Training }\end{array}$ & $\begin{array}{c}\text { Mean } \\
\text { Difference } \\
\text { (I-J) }\end{array}$ & Sig. \\
Operational Force_OF28 & International & $\begin{array}{c}\text { Local and } \\
\text { International }\end{array}$ & $.581^{*}$ & .041 \\
\hline
\end{tabular}

* The mean difference is significant at the 0.05 level. 
Likewise, results in the study also revealed that there was a significant difference in Operational Force criteria on levels of professional training in the organization $\mathrm{F}(2,120)=$ $3.570, p<.05$ for item OF 28. As shown in Table 8, results of the post-hoc comparisons using the Tukey HSD test indicated that there existed a significant difference between the group with international level of training and the group with both local and international level of training. These findings indicate that there was a significant difference for the respondents who went through these two levels of training as they possessed the confidence that they could get everything that they needed to do their jobs. The actual difference in mean scores between the groups was quite moderate with the mean difference of $0.581 *$.

\section{RQ4: Is there a relationship between the professional training level and the length of service among the university staff towards innovation?}

In terms of relationship between the professional training level and the length of service among the university staff towards innovative initiatives, findings showed that there was only a significant relationship between the professional training level and the length of service of $4-6$ years among the university staff (Likelihood Ratio $=28.500, \mathrm{df}=12, \mathrm{p}<$ 0.5 ). The rest of the groups based on the length of service showed that there was no significant relationship with the professional training level towards innovation. Moreover, Table 9 on directional measures depicts that the relationship for the length of service of 4-6 years with professional training level among the university staff is quite weak with eta $=0.07$. In other words, this finding implies that some of the respondents of this study who served the university for 4 - 6 years and had gone through professional training contributed more to innovative initiatives. However, their contributions to innovative initiatives are relatively small due to the directional measures of the data that showed the weak value of eta (eta $=0.07)$.

Table 9. Directional Measures for the Length of Service and Professional Training Level

\begin{tabular}{|c|c|c|c|}
\hline $\begin{array}{l}\text { Length of } \\
\text { Service }\end{array}$ & & & Value \\
\hline $4-6$ years & $\begin{array}{c}\text { Nominal by } \\
\text { Interval }\end{array}$ & $\mathrm{Eta}=0.070$ & $\begin{array}{l}\text { Level of Professional } \\
\text { Training Dependent }\end{array}$ \\
\hline & & & $\begin{array}{l}\text { Innovative Mean } \\
\text { Dependent }\end{array}$ \\
\hline
\end{tabular}

This finding supports Bauld and Mcguiness's (2007) [11] statement that "many people emerged as leaders who have little education or sophistication, and many people who never hold a managerial post demonstrate leadership in a daily basis, not necessary by accomplishing great things, but commanding respect in little things they do" (p. 4). That old myth that "leaders are born, not made" is bunk and should not prevent managers from preventing leaders within their staff.

\section{RQ5: To what extent do the length of service and the level of professional training contributed towards innovative product among the University Staff?}

From the crosstab analysis as displayed in Figure 3, findings in the study suggested that for the 1-3 years length of service, only $30 \%$ of the staff came out with innovative product(s) in their respective faculty. Within $30 \%$ from the 1-3 years length of service, all of the respondents $(100 \%)$ that went through international level of professional training did come out with innovative product(s) in their respective Faculty/Department/ Centre. Only 60\% that went through both local and international levels of Professional Training contributed towards innovative product(s) in their respective Faculty/Department/Centre. Whereas, for the 4-6 years length of service, a total of $75.7 \%$ among the staff came out with innovative product(s) in their respective faculty. The highest percentage that contributed to the innovative product were those staff with the international level of Professional Training with a total of $94.4 \%$. The lowest percentage that came out with innovative product(s) in their respective faculty were the staff that went through local professional training. However, $90 \%$ among the staff who came out with innovative product(s) in their respective faculty were those who underwent local and international Professional Trainings.

For the length of service of 7-9 years, the finding in Figure 3 showed that a total of $63.2 \%$ among the staff came out with innovative product(s) in their respective faculty. The highest percent of staff that contributed to the innovative product were those with both the local and international levels of Professional Training with a total of $83.3 \%$. The lowest percent that came out with innovative product(s) in their respective faculty were the staff that went through local professional training with a total of $44.4 \%$. In contrast, for the length of service of more than 15 years, only $20 \%$ of the staff came out with innovative product(s) in their respective faculty. $100 \%$ that contributed to the innovative products were those staff with the international level as well as the local and international levels of Professional Training. In contrast, $100 \%$ of the staff who had more than 15 years of service and had gone through local professional training did not contribute to the innovative product(s) in their respective faculty. 


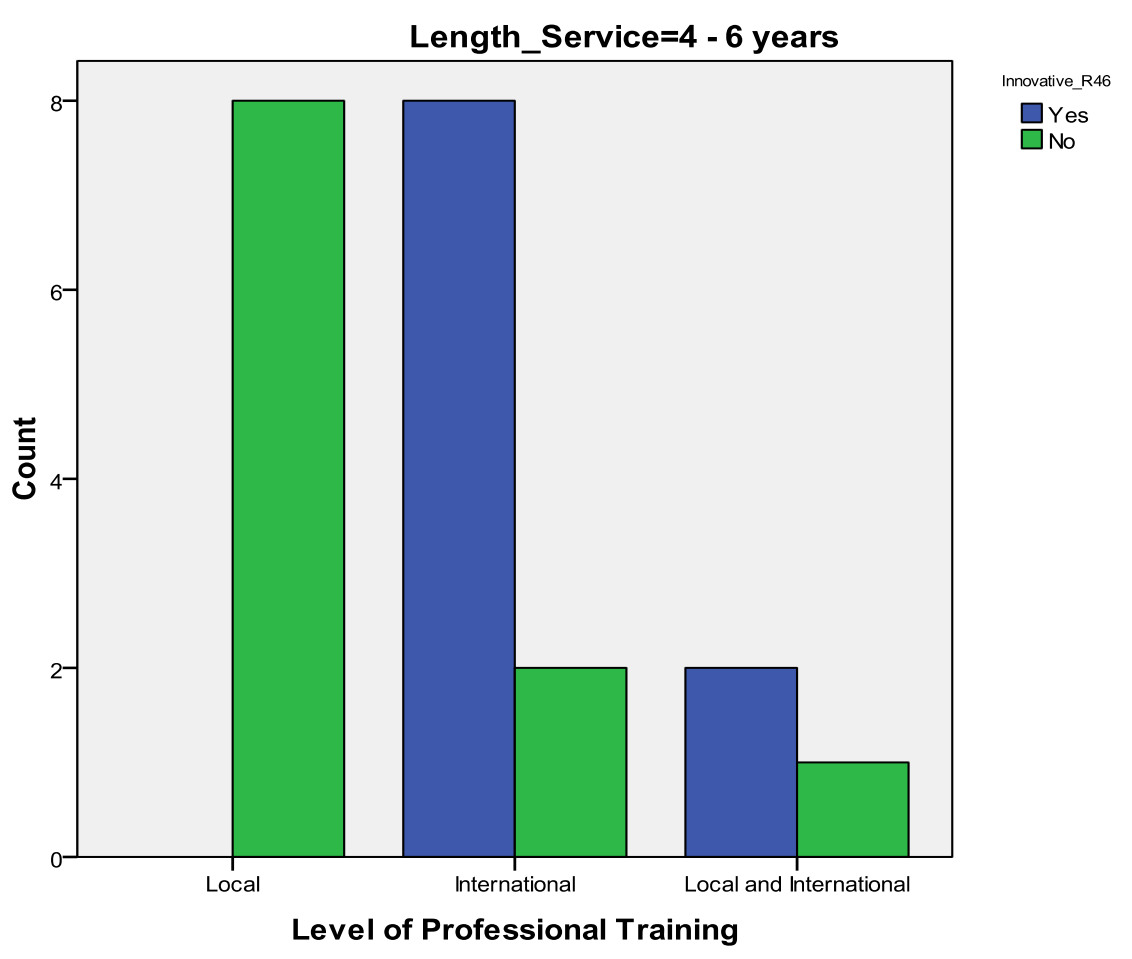

Figure 3. Length of Service and Level of Professional Training on Innovative Product

\section{Discussion}

In general, the findings of this study indicated that customer focus criteria and leadership criteria are the two areas which were perceived by the respondents to be of the utmost importance in making progress as leaders. The findings of the study also showed a significant difference at the $p<.05$ level that occurred for four criteria namely Strategic Planning, Customer Focus, Result and Innovative category in terms of length of service. Likewise, in terms of levels of professional training, there was also a significant difference at the $\mathrm{p}<.05$ level for Leadership, Customer Focus, Work Focus and Operational Force Criteria.

In terms of the leadership criteria, the finding implies that the respondents' faculty knew what they are trying to accomplish and where they are heading for in their future. In fact, mission and vision statements are indispensable communication tools. This finding is in line with TenHoor and TenHoor's (2002, p. 5) [12] emphasis that to be effective, the mission should come from the very bowels of the organization, and represent its most fundamental center. In developing mission and vision statements, all members should participate. This is because involvement breeds commitment and creates a frame of reference for self-governance. It is also imperative that non-profit organizations must have understandable and easily repeatable (easy to remember) vision statements. Vision statements must be universally known and endorsed by all key stakeholders of the organization. Every vision statement must give rise to identifying key measures of success over particular periods of time (Nanus and Dobbs, 1999) [6].

Moreover, this finding also underpinned Bonner's (2010)
[5] statement that highly effective teams are consistently found to be characterized by a clear sense of direction, a deep sense of shared vision and purpose, and a clear understanding of the actions and outcomes that must be produced by the team in order to accomplish its purpose. This is because shared goals and objectives lead to commitments and accountability. Members of effective teams share a sense of common purpose. They are clear about the team's "work" and its importance to the organization's success. They can describe what the team intends to achieve and have developed mutually agreed upon and challenging but realistic goals that clearly relate to the team's vision (Bonner, 2010) [5] . Similarly, this notion is supported by Nonaka's (1991) [4] standpoint that a company's advancement is highly dependent on a shared sense of "what the company stands for, where it is going, what kind of world it wants to live in, and most important, how to make that world a reality" (p. 97).

Referring to the strategic planning criteria, the finding implies that the respondents knew the parts of their organization's plans. This finding is in line with Day's (2007) [13] statement that the most effective succession planning and leadership development initiatives are connected across levels into a coherent whole. By being systematic, the development initiative builds explicit linkages across leadership levels. Specifically, dealing with complexity requires the ability to think strategically, to understand the bigger picture and to appreciate the diverse networks in which an organization operates. According to Bonner (2010) [5], a strategic plan is the typical way non-profit organizations define their direction, priorities and vision. The best strategic and action plans are created jointly with 
board and staff leadership. Strategies and plans that lead to shared goals and objectives must include measurable goals and milestones. This finding indicates that there is less flexibility to make changes when needed.

Relatively, customer focus criteria has the highest score mean of all the criterias. In fact, the authors also agreed that leaders should know who their customers are and make every possible effort to find out their customers' needs and to hear their customers' voices. This stems from the fact that organizations are judged most by the quality and quantity of the clients they have served and currently serve. Leaders should understand the distinction between "customer" and "boss" and act accordingly to balance competing demands. Morever, leaders ought to understand the importance of measuring and monitoring the degree to which their customers' needs are met or exceeded. They should also continually strive to improve the customer focus criteria.

In terms of the measurement criteria, the finding implies that the University staff knew how to measure the quality of their work. According to Bonner (2010) [5], non-profit organizations should have dashboards or key performance measures (or metrics) that everyone can understand and follow. Key performance metrics are quantifiable measurements, agreed to beforehand, that reflect the critical success factors of an organization. This viewpoint is also in tandem with Hucama's (2011) [14] perception that key performance indicators help to ensure focused and business oriented efforts in order to develop an organization. The authors also support this view as they believe that setting reachable key performance indicators serve to guide employees to pace forward for their organization to grow and achieve its goals.

Relating to the work focus criteria, the finding implies that the respondents cooperate and work as a team. In fact, this finding is inline with Bonner's (2010) [5] finding which defined "healthy and effective leadership teams" as having all of the following characteristics; such as implementing shared purpose, goals and values; understanding the specific roles and decision-making authority of each member, working collaboratively as a unit with a high degree of trust and respect; creating an effective communication processes that facilitate problem-solving, decision-making and conflict resolution and all team members have high levels of technical, functional and interpersonal skills. Moreover, Takeuchi and Nonaka (1986) [15] also advocated that the growth of an organization relies on the different functional teams that collaborate and work together on a shared division of labour.

Pertaining to the operational force criteria, the finding supports TenHoor and Tenhoor's (2002, p. 6) [12] statement in emphasizing that goals are operationalized through objectives for which individuals are responsible. In fact, self-managing teams provide a variety of benefits, but they require the development of group process skills to operate effectively. Leadership is a process or set of functions that may be performed by many of a team's members (Day, Gronn \& Salas, 2004) [16] . This stance concurs with
Amabile's (1988) [17] point of view that management skills, as well as relevant branch, division and project level skills are important factors in deciding an organization's success. In addition, "a good management should be professional, balance freedom and constraint, and communicate openly" (Amabile, 1988, p. 155) [17]. Where as for the result criteria, the findings indicated that the respondents felt that their customers are satisfied with their work, as well as their organization obeys laws and regulations. Mello (2010) [18] explained that in understanding customers' needs and designing products and services that are related to their lives can enhance customers' satisfaction. Thus, this in turn will motivate employees to be more creative and to be engaged in innovation. On another note, Tyler (2006) [19] advocated that obeying laws and regulation provides support for the value of legitimacy as a motivating force in the area of law for the organization to function in its highest capacity. Hence, this helps to maintain social order by regulating the employees' behaviour.

In addition, findings in this study indicate that respondents who were exposed to both international and local professional training exhibited greater confidence in innovative initiatives pertaining to the four criteria in making progress as leaders: Leadership, Customer Focus, Work Focus and Operational Force Criteria. Likewise, in terms of the relationship between professional training level and length of service among the university staff towards innovative initiatives, findings showed that university staff with the length of service of $4-6$ years and had gone through international professional training contributed more innovative initiatives than the rest of the groups. Hence, these findings imply the importance in the relationship between exposure to the types of professional training and the length of service of the staff in an organization. These findings concur with the findings of various research which showed that professional development can enhance the skills of both new and longtime staffers. Seyed Ebrahim et al.'s (2014) [20] findings revealed that the length of service was related to continuance and occupational commitment. Likewise, Popoola's (2006) [21] study found that length of service might affect the organizational commitment in Nigerian state universities. Moreover, findings in Chang and Choi's (2007) [22] study related to determining the effect of years of service on the organizational commitment of workers, suggested the importance of maintaining a balance between organizational and professional commitment as well as providing a method for identifying the critical period for interventions designed to increase retention of Research and Development (R\&D) professionals during their early organizational socialization.

\section{Conclusions}

From the findings of this study, it can be concluded that the two salient criteria in making progress as leaders are the customer focus criteria and the leadership criteria. Majority 
of the respondents knew who their faculty/department's most important customers are, they perceived that their faculty/department were aware of their organization's mission, they knew who their organization's most important customers are, they cooperated and worked together as a team, they perceived that their customers are satisfied with their work, they had control over their personal work processes and they perceived that their faculty/ department knew their organization's vision. Thus, this indicates that shaping leaders with these qualities is essential to attain advancement and to be creative and innovative. In fact, knowledge and skill in accountability structures are collective goods, not private goods. That is, the knowledge and skill necessary to improve the performance of schools do not belong to those schools, or to people who work in them, but belong to the system as a whole (Elmore, 2006) [7]. Similarly, Nonaka (1991) [4] supports the notion of teamwork as an important part of innovation as the team members "provide interaction, conflict, critical thinking, reflection and constant dialogue" (p. 104) to attain quality.

The finding in this study that leadership criteria was perceived to be one of the key criteria in making progress as leaders is also deemed agreeable by the authors. The authors believe that good organisation management lies on the shoulders of the key leaders who illuminate the path to be followed by the group members. As Nonaka (1991) [4] advocated that senior executives "are the true "knowledge engineers' of the "knowledge-creating company"' (p. 104) as they help to build connections with external forces to foster support for innovation as it surfaces, and share their views of the organizational environment with innovative employees.

Besides that, the findings in the study indicated that operational force criteria was the least preferred by the respondents as the criteria in making progress as leaders. Although this finding pointed to the propensity of the respondents' focus was towards result oriented rather than operational critera, the authors opined that operational force criteria is equally as important as the result criteria in making progress as leaders.

In addition, the findings in the study suggested that there was only a significant relationship between the professional training level and the length of service of $4-6$ years among the university staff. The rest of the groups based on the length of service showed that there was no significant relationship with the professional training level towards innovation. Nevertheless, the findings showed that majority of the staff who contributed to innovative product were those with international level of Professional Training. The lowest percentage that came out with innovative product(s) in their respective faculty were the staff that went through local professional training. Besides that, it was found that staff who worked for more than 15 years with the organization and had gone through local professional training did not contribute to the innovative product(s) in their respective faculty. This indicates that besides providing exposure to local professional training, staff also needs to be given more international training exposure opportunities. Effective training focused on developing the thinking skills associated with creativity, hence leading to concrete outcomes in terms of quantity and quality of creative and innovative output (Basadur, Graen and Scandura, 1986) [23]. In other words, by emphasizing on teaching methods and training groups to be creative in their thinking, it is important to emphasize the process rather than the product. Nevertheless, training programs need to be monitored and reinforced in the organization in order to lead to desirable impact.

\section{REFERENCES}

[1] Davis, R. (2007). Leadership starts with you. Executive Forum. doi: 10.1002/Itl.229

[2] McCauley, C. (2011). Making Leadership happen a White Paper. Center for Creative Leadership. Retrieved from: www.ccl.org

[3] Southern Regional Education Board. (2007). Schools need Good Leaders now: State progress in creating a Learning-Centered School Leadership System. Atlanta. Retrieved from: 9211 www.sreb.org 2007

[4] Nonaka, I. (Nov-Dec 1991). The Knowledge-Creating Company. Harvard Business Review, 69, 96-104.

[5] Bonner, L. (2010). Building Healthy and Effective Non-profit Leadership Teams. U. S. A.

[6] Nanus, B. and Dobbs, S. M. (1999). Leaders who make a Difference: Essentials Strategies for Meeting the Non-profit Challenge. San Francisco: Jossey- Bass.

[7] Elmore, R. F. (June, 2006). Leadership As The Practice of Improvement Preliminary Draft. OECD Activity On Improving School Leadership. Paper presented at International Conference: International Perspectives on School Leadership for Systemic Improvement.

[8] Global Human Capital Trends 2014: Engaging the 21 st-century workforce. A report by Deloitte Consulting LLP and Bersin. United Kingdom: Deloitte University Press.

[9] Cronbach, L. J. (1991). Essentials of Psychological Testing. New York: Harper \& Row.

[10] Souba, W. W. (2007). The Leadership Dilemma. Journal of Surgical Research, 138, 1-9. doi:10.1016/j.jss.2007.01.003

[11] Bauld, S. and McGuiness, K. (2007). Exercising Leaderships. U. S. A.: Public Sector Purchasing.

[12] TenHoor, W. J. and TenHoor, M. S. W. (2002). A Guide for Consumer Organization Leadership: Principles for Practice. Lawrence, Massachusetts: The National Empowerment Center, Inc. Retrieved from: http://samhsa.gov/ recoverytoproactice/

[13] Day, D. V. (2007). Developing Leadership Talent: A Guide to Succession Planning and Leadership Development. U. S. A.: SHRM Foundation.

[14] Hucama. (2011). Organizational Key Performance Indicators - A Management Tool with Bottom Line Effect. Copenhagan: Human Capital Management. Retrieved from: 
http://www.hucama.com

[15] Takeuchi, H. and Nonaka, I. (Jan-Feb 1986). The New Product Development Game. Harvard Business Review, 137-146.

[16] Day, D., Gronn, P. and Salas, E. (2004). Leadership Capacity in teams, Leadership Quarterly 15(6), 857-880.

[17] Amabile, T. M. (1988). A Model of Creativity and Innovation in Organizations. Research in Organizational Behavior, 10, 123-167.

[18] Mello, J. (2010). Innovation Perspective: Motivation for Innovation. Retrieved from: http://www.innovationexcellenc e.com

[19] Tyler, T. R. (2006). Why People Obey the Law. U. S. A.: Princeton University Press.

[20] Seyed Ebrahim Jafari Kelarijani, Ali Reza Heidarian, Reza
Jamshidi and Mohamad Khorshidi. (2014). Length of Service and Commitment of Nurses in Hospitals of Social Security Organization (SSO) in Tehran. Caspian Journal of Internal Medicine, 5(2), 94-98.

[21] Popoola, S. O. (2006). Personal Factors Affecting Organizational Commitment of Records Management Personnel in Nigerian State Universities. IFE Psychologia,14, 183-97.

[22] Chang J. Y and Choi J. N. (2007). The Dynamic Relation between Organizational and Professional Commitment of Highly Educated Research and Development (R\&D) Professionals. Journal of Social Psychology, 147(3), 299315.

[23] Basadur, M., Graen, G. B. and Scandura, S. G. (1986). Training Effects on Attitudes toward Divergent Thinking among Manufacturing Engineers. Journal of Applied Psychology, 71(4), 612-661 